\title{
Wheat Production as Affected by Weed Diversity and Other Crop Management Practices in Ethiopia
}

\author{
Bogale Ayana* \\ Ethiopian Institute of Agricultural Research, Holeta Agricultural Research Center, P.O. BOX 2003, Addis \\ Ababa, Ethiopia
}

*Corresponding Authors: Bogale Ayana, Ethiopian Institute of Agricultural Research, Holeta Agricultural Research Center, P.O. BOX 2003, Addis Ababa, Ethiopia

\begin{abstract}
Wheat is one of staple and major food security crops which can be cultivated from small to large scale farms in Ethiopia. Therefore, the aim is to determine influence of weed and other abiotic stresses on wheat production under rain fed and irrigated areas. It was rich sources of different nutrients which contain higher percentage of starch followed by protein and other types of nutrients. Traditionally, the crop is used for making bread, Dabokolo, porridge, Kinche and other types of foods. The straw is good source for animal feed and also used for thatching roofs in rural areas. Wheat production was limited due to various biotic and abiotic factors. Many varieties of wheat were released by agricultural research institute in Ethiopia that were suited for different soil types and climatic conditions. The crop competes with weeds for various growth resources like nutrient, light, Carbon dioxide, space, moisture etc. during its growth. The competition can be intra and inter specific completion. Planting densities can determine plant population in the field. Planting fewer seeds below the recommendation in the plots may exert severe competition of weeds but planting of higher seed rates created problem of lodging, disease infestation and rat damage. Increased plant density per unit area achieved by higher seed rates probably caused smothering of weeds and consequently reduced their dry matter. Weed competition is most serious when the crop is young and at active growth stage. Weed losses in wheat may occur from initial stages to the last stage of maturity, harvest, threshing, winnowing and storing of wheat grains. Weeds can be controlled by different methods but chemical weed control in wheat was best in producing higher grain yield than hand weeding. A wide variety of herbicides are available for both annual grassy and broadleaf weed control in wheat. Application of grassy and broad leaf herbicides increased grain yield and yield components of wheat. Several investigations were made for the management of weeds in wheat fields. Studies on annual weeds control in wheat was done by many researchers in Ethiopia as well as outside the country but still there is yield gaps. Therefore, further study on weed management in wheat will be needed for various weed flora throughout the country.
\end{abstract}

Keywords: competition; crop; plant; weed; wheat

\section{INTRODUCTION}

Wheat belongs to the family Poaceae and the genus Triticum. The global annual wheat production is 731.6 million metric tons from an area of 215.87 million hectares giving an average yield of 3.39 metric tons ha $\mathrm{h}^{-1}$ (USDA,2019).In Ethiopia, it is one of the major staple and strategic food security crop with an average annual production and productivity of 4.64 million tones and 2.73 tons ha ${ }^{-1}$ respectively (CSA,2018). Wheat has great nutritional value and contains starch (60-90\%), protein (11-16.5\%), fat (1.5-2\%),inorganic ions(1.2-2\%) and vitamins (Ali et al., 2014). Bread wheat is known to be a major source of energy and protein. Traditionally the crop is used for making bread, Dabokolo, porridge, Kinche and other types of foods. The straw is good source for animal feed and is also used for thatching roofs (Mathewos et al.,2012).

Although wheat has a great nutritional and economic importance, its productivity has been constrained due to various biotic and abiotic factors(Haidar et al.,2014).Among the biotic factors weeds are one of the major constraints in wheat production as they reduce productivity due to competition, allelopathy and by providing habitats for pathogens as well as serving as alternate host for various insects, fungi and increase harvest cost (Abbas et al.,2009).Studies indicated that crop losses due to weed competition throughout the world are greater than those resulting from combined effects of insect pests and diseases (Amare et al.,2014).The yield loss caused by weed infestations in wheat ranges from $10-65 \%$ 
depending up on the weed species, their density and environmental factors(Gezu and Soboka,2001;Oerke and Dehne,2004). .

In Ethiopia, where wheat is cultivated, poor weed management and indefinite and below optimum plant population used by the farmers appear to be the major limiting factors resulting in low productivity of wheat (Zegeye et al.,2001).In most cases, wheat is grown in the country without appropriate seed rate, sometimes farmers use below optimum seed rate that resulted in poor stand establishment encouraging growth of weeds. On the other hand, higher seeding rate may exacerbate problems like lodging, insect and disease infestation and rat damage that harm crop yield (Bibi et al., 2008;Abbas et al.,2009 ).Therefore the aim of this article is to determine influence of weed and other abiotic stresses on wheat production under rain fed and irrigated areas.

\section{Wheat Production Constraints}

\subsection{Wheat Production and Ecology}

In Ethiopia, wheat was planted to $13.38 \%$ (1,696,907.05 hectares) of the grain crop area in $2018 / 19$ cropping season (CSA,2018).The production obtained from wheat was $15.17 \%(46,429,657.12$ quintals) of the grain production and yield of $2.73 \mathrm{t} \mathrm{ha}^{-1}$ (CSA, 2018). Some of the common bread wheat varieties under production in Ethiopia includes: Dendea, Digelu, Kekeba, Galema, Alidoro, Hidassie, Kubsa, Batu, Mitike, Wabe, Simba, Hawi, Warera, Dure, Dodota, Meraro, Abolla, Pavon, Dashen, Kenya -1, Densa, Simbo, Megal, Enkoy and Laketch (HAR,2019).

Table1. Wheat production regions of Ethiopia under private peasant holdings for 2018/19 Meher Season (CSA,2018).

\begin{tabular}{|l|l|l|l|l|}
\hline Regions & No of holders & $\begin{array}{l}\text { Area of production } \\
\text { (ha) }\end{array}$ & Production ton/ha & Yield ton/ha \\
\hline Tigray & 312708 & 107929.86 & 214003.14 & 1.98 \\
\hline Afar & - & - & - & - \\
\hline Amhara & 1645432 & 554661.74 & 1404707.481 & 2.53 \\
\hline Oromia & 1713504 & 898682.57 & 2669917.77 & 2.97 \\
\hline Somali & - & - & - & - \\
\hline BenishangulGumuz & 8455 & 2455.71 & 5908.35 & 2.41 \\
\hline SNNP & 525386 & 127246.59 & 34919.60 & 2.67 \\
\hline Gambella & - & - & - & - \\
\hline Harari & 3405 & - & - & - \\
\hline
\end{tabular}

Wheat can be cultivated in a wide range of agricultural environments (Farooq et al., 2009). It can grow over a wide range of elevations, climatic conditions, and soil fertility conditions. The crop is grown at an altitude ranging from 1500 to 3000 meters above sea level (m.a.s.l.) between 6-16 ${ }^{\circ} \mathrm{N}$ latitude and 35$42^{\circ} \mathrm{E}$ longitude in Ethiopia. The most suitable agro-ecological zones, however, fall between 1900 and 2700 m.a.s.l. (Bekele et al., 2000). Even though the optimal growing temperature is $25^{\circ} \mathrm{C}$, it can be grown in temperatures ranging from 3 to $32^{\circ} \mathrm{C}$. The ideal daily temperature for different stages of wheat development varies from $20-25^{\circ} \mathrm{C}$ for germination, $16-20^{\circ} \mathrm{C}$ for good tillering and $20-26^{\circ} \mathrm{C}$ for proper plant development. The optimal rainfall for wheat is between $900-1100 \mathrm{~mm}$ throughout the growing season, but wheat can be grown in xerophytic to littoral moisture regimes with average annual rainfall between 250 to $1750 \mathrm{~mm}$. Wheat can be grown under different soil types but well-drained fertile loamy to sandy loam soil with a $\mathrm{P}^{\mathrm{H}}$ of 6 to 7.5 is suitable for its growth (Tana et al., 2018).

\subsection{Common Weed Species Associated with Wheat}

Wheat field infested by variety of weed species belonging to different families. The weed flora composition assessment in wheat fields in Ethiopia showed that Avena abyssinica L., Avena fatua L., Bromus pectinatus L., Lolium temulentum L., Phalaris paradoxa L., Setaria pumila L., and Snowdenia polystachya $\mathrm{L}$. are the major problematic weed species in wheat growing regions (Birhanu, 1985; Rezene, 1985; Tanner and Grief, 1991).

The most widely spread and distributed broadleaved weeds and most problematic weeds in wheat crop weeds include: Amaranthus hybridus L., Argemone mexicana L., Bidens pilosa L., Commelina africana L., and Chenopodium album L. Convolvulus arvensis L.,Datura stramonium L.,Galinsoga parviflora 
Cav., Guizotia scabra (Vis) Chiov, Medicago polymorpha L., Polygonum nepalense L., Plantago lanceolata L. and Scorpiurus muricatus L. (Rezene, 1985; Tanner and Giref, 1991).

\subsection{Weed-Crop Competitions for Growth Resources}

The word competition comes from the Latin word compete, which means to ask or sue for the same thing another does. Competition in biology, ecology and sociology is a contest between organisms, animals, individuals, groups, etc., for territory, a niche or a location of resources, for resources, mates, for prestige, recognition, awards or group or social status for leadership. According to Thompson, and Grime (1979) competition is established when neighboring plants use the same resources and success in competition is strongly determined by the plant capacity to capture these resources. Thus, a good competitor has a high relative growth rate and can use the available resources quickly. However, Tilman (1980) claims that competitive success is the ability to extract scarce resources and to tolerate this lack of resources - essentially to be more efficient in extracting and using a given resource. Competition between plants is different from the competition between animals. Due to the lack of mobility, the Competition among plants apparently is passive, not being visible at the beginning of the development (Munch et al., 2008). It is known, however, that crops in general terms do not present high competitive ability against weed species due to the genetic refinement they were submitted to increase the occurrence of desired productive features in detriment of aggressiveness (Ainsworth and Rogers, 2007). Therefore, in theory, a good competitor could be the species with least resource requirement (Radosevich et al., 2007).

In agricultural systems, both the crop and weeds grow together in the same area. As both groups usually demand similar environmental factors as water, light, nutrients and $\mathrm{CO} 2$, and usually these resources are not enough even for the crops, the competition is established. Under this situation, any strange plant which emerges at this area will share these limited resources, causing a reduction both in the volume produced by the crops, as well as in the quality of the harvested product (Munch et al., 2008). Radosevich et al. (2007) classified the environmental factors which determine plant growth in resources and conditions. Resources are the consumed factors such as water, $\mathrm{CO} 2$, nutrients and light, and the response of plants usually follows a standard curve: it is small if the resource is less available and maximum at the saturation point, usually declining again in case of excessive availability of the resource (e.g. toxicity due to excessive zinc availability in the soil). Conditions are factors not directly consumed, such as $\mathrm{P}^{\mathrm{H}}$ and soil density, although they influence directly plant ability in exploring the resources. However, plant competition will only be established when the demand of a given resource by a plant community surpasses the ability of the environment in supplying the demanded level of the given resource (Munch et al., 2008).

\subsection{Effects of Weed Competition on Growth and Yield of Wheat}

Weeds are plant which compete for nutrients, space, light and exerts lot of harmful effects by reducing the quality as well as quantity of the crop if the weed populations are left uncontrolled (Alemaw and Agegnehu ,2019). Weeds cause diseases in crops and support the insect pests. In agricultural term weeds are called pests because they cause damage to the crop. Weeds may reduce about 40-50\% grain yield in wheat crop .Among the factors, which adversely affect the yield of wheat crop, weed infestation is the most harmful one but less noticeable. Weeds comprise the most undesirable, aggressive and troublesome element of world's vegetation. Weeds are plants, which grow out of their proper places and whose virtue has not yet been discovered. Weeds also act as reservoir for multitude of pest and diseases, which use them as alternate hosts for food and shelter during the off season period. Weed density under both rained as well as irrigated conditions were studied for yield losses due to various densities of Melilotus indica L.( Oad et al., 2007)

Wheat is attacked by different agricultural pests, but weeds remained the major problem play the main role. Weed losses in wheat may occur from initial stages to the last stage of maturity, harvest, threshing, winnowing and storing of wheat grains. Weed plants are more resistant, hardy and making faster growth than wheat and cause great growth and yield loss due to competition before crop harvest. Generally weeds reduce wheat yield by $30-50 \%$.Losses may reach $100 \%$ depending on weed species and density (Tessema and Tanner, 1997). However, different workers reported different estimations of wheat yield losses depending on the infesting weed species, crop cultivar and their densities and the agricultural practices employed. 


\subsection{Critical Period of Crop-Weed Competition in Wheat}

Critical period of crop-weed competition (CPC) represents the time interval between two separately measured components; the maximum weed-infested period or the length of time that weeds which have emerged with the crop can remain before they begin to interfere with crop growth, and the minimum weed-free period or length of time a crop must be weed-free after planting in order to prevent yield loss. Competition may be interspecific between two or more plants belonging to different species of weeds or crops or intraspecific between plants of the same species which may be crop or weed species (Tana et al., 2018).Weed competition is most serious when the crop is young and at active growth stage.It is essential in reducing weed control expenses. Weeds at this period must be removed by any mean or in economic language it is the shortest time span in the ontogeny of crop growth when weeding result in the highest economic returns.It is determined by crop species and cultivars, weed species and density, agricultural practices employed and prevailing environmental conditions.

Terefe et al. (2016) reported that the critical periods of weed competition in wheat ranges between 1545 days after sowing (DAS) and also the critical weed competition period in wheat is 30 to 60 days after sowing. It occurs between 32 to 40 days after sowing and between 30-50 days after sowing (Chaudharyet al.,2008).The critical period of weed-crop competition generally lies approximately between equal to the first one-third to one-half of the life cycle of the crop. Therefore, weeds that are present before or emerge after this period do not cause significant yield losses. Thus, crop yield obtained by weeding during critical period of weed competition is almost similar to that obtained by the full season weed-free conditions (Tana et al., 2018).

\subsection{Effects of Seed Rates on Weed Management and Productivity of Wheat}

Optimum seeding rate is essential in determining the size of weed infestation in the field. This rate means ideal number of wheat plants per unit area that allow highest yield and smothering of weed. It is well established that yield increased with seeding rate up to a certain rate level after which no more increase obtained per plant basis while increasing rate per unit area is greatly decreased or kept steady or unchanged after certain plant density. The concept was termed as "the constant final yield". Optimum seeding rate minimize the space available between plants and rows which may be occupied by weeds. However, farmers should not exceed this rate in order to avoid any intraspecific competition effects of crop plants (Rao and Nagamani, 2010).

Planting fewer seeds may increase weed growth. Generally, high seeding rates should be increased when seeding is delayed beyond the optimum dates to compensate for reduced tillering (Shah et al., 1994).Row spacing is in direct link with seeding rate and availability of water and nutrients. Under low soil moisture and fertility level planting distance between plants and rows may be increased to allow enough space to be exploited by individual crop plant. This however, opens the way for weed invasion and occupation of space available.

Weed control by hoe or herbicides should be implemented between rows. Wide rows associated with low seeding rate allows more crop tillering and facilitate mechanical weed control. Removed weeds vegetation may be laid into between rows (soil cover) to prevent any subsequent weed seed germination or growth. However, when moisture and nutrients are unlimited, narrow rows and increased crop density offer advantages for weed control. Emerged weed seedling strongly suffered from both shading and competition effects of tall growing wheat plants. Narrow + row spacing can improve weed control during the fallow periods because weeds are smaller and more easily controlled with herbicides than they are in wide row (Derksen et al., 2002).

Bhan et al. (1987) concluded that increasing seedling rate from 100 to $150 \mathrm{~kg} \mathrm{ha}^{-1}$ significantly reduced the dry matter of weeds and increased grain yield of wheat. Nazir et al. (1987) reported that $100 \mathrm{~kg} \mathrm{ha}$ ${ }^{1}$ was the most effective in producing taller plants and higher yield as compared to low seedling rate. Mennan and Zandstra (2005) reported that decreasing the seeding rate from $250-200 \mathrm{~kg} \mathrm{ha}^{-1}$ decreased wheat yield in the presence of weed.

Sharma and Singh (2011) found that Weed population was significantly lower in crop sown at higher seed rates of $150 \mathrm{~kg}$ and $125 \mathrm{~kg} / \mathrm{ha}$ as compared to recommended seed rate of $100 \mathrm{~kg} \mathrm{seed} / \mathrm{ha}$ and lowest seed rate of $75 \mathrm{~kg}$ seed/ha though the differences between higher seed rates of $150 \mathrm{~kg} / \mathrm{ha}$ and $125 \mathrm{~kg} / \mathrm{ha}$ were statistically at par with each other. Increased plant density per unit area achieved by 
higher seed rates probably caused smothering of weeds and consequently reduced their dry matter. Further, successive increments of seed rate from 75 to $150 \mathrm{~kg} / \mathrm{ha}$ significantly reduced dry matter accumulation of weeds. Seed rate of $150 \mathrm{~kg} / \mathrm{ha}$ reduced $6.5,13.6$ and $30.3 \%$ in the first year and 3.2, 8.2 and $19.4 \%$ in the second year, dry matter of weeds compared to 125,100 and $75 \mathrm{~kg}$ Seeds /ha, respectively.

Gill (2008) also observed that seed rate influenced the weeds dry matter effectively as the seed rates increased, the competition among crops increased which shows excellent smothering effect. Wheat seed rates significantly influenced grain and biomass yield, spike per unit area and kernel weight. Haile and Girma (2010) found that increasing seed rate over recommended $\left(150 \mathrm{~kg} \mathrm{ha}^{-1}\right)$ by 25 and $50 \%$ to 187.5 and $225 \mathrm{~kg} \mathrm{ha}^{-1}$ increased wild oat control efficacy by 16.9 and $21.5 \%$ respectively. Similarly, maximum weed control efficiency under $150 \mathrm{~kg} / \mathrm{ha}$ seed rate and minimum under $75 \mathrm{~kg} / \mathrm{ha}$ seed rate .Sharma and Singh (2011) concluded that sowing at $125 \mathrm{~kg} \mathrm{seed} / \mathrm{ha}$ with post-emergence application of sulfosulfuron at $25 \mathrm{~g} / \mathrm{ha}$ at $30 \mathrm{DAS}$ is the most economical and efficient weed management practice for achieving high yield in wheat. Marwat et al. (2011) observed that integrating line sowing with higher seed rate $\left(150 \mathrm{~kg} \mathrm{ha}^{-1}\right)$ and herbicides (Buctril super) could suppress weeds.

\subsection{Effects of Herbicide Application on Weed Management and Productivity of Wheat}

Herbicides should be used in combination with good preventative, physical and cultural practices. A wide variety of herbicides are available for both annual grassy and broadleaf weed control in wheat. The effectiveness of the herbicide will depend upon a number of application and environmental factors. Most herbicides are recommended at a range of rates either to facilitate control of weeds in a window of growth stages or under differing densities. Weed control is always easier and less disruptive to the crop when done at an early growth stage on the weeds. Decreasing the water carrier volume can increase the danger of spray drift result in inadequate coverage of the weed species and cause yield damage. According to Tanner and Grief (1991) broadleaf herbicides in the first decade of research as the phenoxy compounds provided adequate control. Subsequent to the shift in the weed spectrum towards phenoxytolerant broadleaf species, broadleaf herbicide screening increased in the early 1980s.

On the other hand, reliance solely on chemical weed control involves excessive use of herbicides, resulting in pollution of the environment and inter and intra-specific shifts (Hassan and Marwat, 2001) due to the development of more competitive herbicide-resistant biotypes within a plant population or community (Shrestha et al., 2010).In addition, herbicide use reduces N-uptake in wheat (Azad, 1997) leading to low growth and yields. This is especially true in the case of non-selective herbicides as reported by Malhi et al. (2007) who observed a significant reduction in plant $\mathrm{N}$ uptake in wheat by applying a mixture of non-selective (glyphosate) and selective (2,4-D) herbicides. For most infestations, the selective use of herbicides is necessary. However, the uses of herbicides in conjunction with cultural and mechanical control methods usually result in the most effective management of weeds (Egan et al., 1993).

Ahmad et al. (1993) observed that herbicides application decreased dry weight of weeds significantly compared to dry weight in non-treated plots. Chemical weed control in wheat was best in producing higher grain yield than hand weeding. Akhtar et al. (1991) found that application of grassy and broad leaf herbicides increased grain yield and yield components of wheat.

Several investigations were made for the management of weeds in wheat fields. Studies on annual weeds control was done by many researchers in Ethiopia as well as outside the country. Accordingly, Dawit et al. (2014) was found that Pallas 45 OD had better weed control efficiency of broad spectrum especially for controlling serious weeds like G. palviflora, G. scabra and from grassy weeds Avena fatua L., P. paradoxa and Phalaris minor L. which were serious at Babicho and Faate. Move over, the highest weed suppression were from the combination of Pallas 45 OD with 2, 4-D and twice hand weeding followed by Derby +Pallas $45 \mathrm{OD}$ and the highest was from weedy check and single herbicide application either for grass or broad leaf purposes (Zahara and Shigute,2017). The results of the present investigations we conclude that: annual weed species like Amaranthus hybridus L., Argemon Mexicana L., Bindens pilosa L., Commelina benghalensis L., Datura stramonium L.,G. parviflora, G. scabra, $P$. lanceolata and Xanthium strumarium L. were highly managed by these sequential herbicides application (Zahara and Shigute,2017). Megersa et al. (2017) observed various weed species such as $G$. scabra, P. nepalense ,S. arvensis, R. raphanistrum, Achyranthes aspera, A. fatua and S. pumila were 
effectively controlled by the application of Pallas 45 OD. It was also found that Pallas 45 OD decreased weed density by $79.8 \%$ and $81.8 \%$ at Shambo and Gedo, respectively. Pallas 45 OD was more effective on controlling broadleaved weeds which reduced the weed population as compared to 2, 4-D and also it can control serious grassy weeds on wheat (Bekele et al., 2018). In addition to this, the application of 2, 4-D EE $1 / 4 \mathrm{ha}^{-1}+1 / 4 \mathrm{lha}^{-1}$ Pallas 45 OD has better herbicide efficacy could be the best option for weed management for wheat production. The grain yield of the Pyroxulam treatment was higher than the hand weeding treatment in all districts which could be due to the effectiveness of the herbicide in reducing weed competition at all stage of the crop. Wild oat control efficacy was varied highly among the herbicide rates and application timings. It was found that application of Topic $1 \mathrm{~L} \mathrm{ha}^{-1}$ is more effective in controlling the target weed species.

\section{CONCLuSion}

Wheat is one of the major staple and strategic food security crops in Ethiopia. It can be grown over a wide range of elevations, climatic conditions, and soil fertility conditions. Among the biotic factors weeds are one of the major constraints in wheat production as they reduce productivity due to competition, allelopathy and by providing habitats for pathogens as well as serving as alternate host for various insects, fungi and increase harvest cost .The yield loss caused by weed infestations in wheat ranges from 10-65\% depending up on the weed species, their density and environmental factors. Wheat field infested by variety of weed species belonging to different families. Weeds compete with crop for various resources. Competition is established when neighboring plants use the same resources and success in competition is strongly determined by the plant capacity to capture these resources. Weeds may reduce about 40-50\% grain yield in wheat crop .Among the factors which adversely affect the yield of wheat crop, weed infestation is the most harmful one but less noticeable. Critical weed competition period in wheat is 30 to 60 days after sowing. Optimum seeding rate is essential in determining the size of weed infestation in the field. Increasing seedling rate from 100 to $150 \mathrm{~kg} \mathrm{ha}^{-1}$ significantly reduced the dry matter of weeds and increased grain yield of wheat. Weed can be controlled by different methods but chemical weed control in wheat was best in producing higher grain yield than hand weeding. A wide variety of herbicides are available for both annual grassy and broadleaf weed control in wheat. Application of grassy and broad leaf herbicides increased grain yield and yield components of wheat. Several investigations were made for the management of weeds in wheat fields. Studies on annual weeds control in wheat was done by many researchers in Ethiopia as well as outside the country but still there is yield gaps. Therefore, further study on weed management in wheat will be needed for various weed flora throughout the world.

\section{REFERENCES}

[1] Abbas, S.H.,Saleem,M.,Maqsood,M., Mujahid, M.Y. and Saleem, R.,2009.Weed density and grain yield of wheat as affected by spatial arrangements and weeding techniques under rainfed conditions of Pothowar. Pakistan Journal of Agricultural Science, 46(4): 242-247.

[2] Ahmad, K.,Z., Shah, Khan, M. K. and Khan, M.Q.,1993.Effect of post - emergence herbicides application and hand weeding on wheat and weed pressure. Pakistan Journal of Weed Science Research, 6 (1-2): 40-45.

[3] Ainsworth, E.A. and Rogers, A., 2007. The response of photosynthesis and stomatal conductance to rising CO2: mechanisms and environmental interactions. Plant, cell and environment, 30(3):258-270.

[4] Akhtar, M.Q., Hamayoun, M.B., Gill and Nazir,M.S.,1991.Comparative Study of various crop management practices on the weed growth and wheat yield. Sarhad Journal of Agriculture, 7(2): 91-94.

[5] Alemaw, G. and Agegnehu, G., 2019. Precision Agriculture and the Need to Introduce in Ethiopia. Ethiopian Journal of Agricultural Sciences, 29(3):139-158.

[6] Ali,H., Tahir, M. and Nadeem,M.A.,2014.Determining Critical Period of Weed Competition in Wheat under Different Tillage Systems.life, 12(2) :74-79.

[7] Ali,H.,Tahir,M.and Nadeem,M.A.,2014.Determining Critical Period of Weed Competition in Wheat under Different Tillage Systems.life, 12(2),pp.74-79.

[8] Amare,T.,Sharma,J.J. and Zewdie,K.,2014.Effect of weed control methods on weeds and wheat (Triticum aestivum L.) yield. World journal of agricultural research, 1(2):124-128.

[9] Amare,T.,Sharma,J.J. and Zewdie,K.,2014.Effect of weed control methods on weeds and wheat (Triticum aestivum L.) yield. World journal of agricultural research, 1(2), pp.124-128. 
[10] Babu, R.S.K.,Kakraliya, Prakash,L.,Kumar,P. and Yadav,R.A.,2017.Effect of Plant Geometry and Seed Rates on Growth, Yield Attributes, Productivity As Well As Weed Dynamics of Wheat (Triticum aestivum L.). International Journal of Current Microbiology and Applied Science, 6(3): 81-88.

[11] Bekele,B., Dalga, D. and Zemach,S.,2018.Effect of Weed Management on Yield Components and Yield of Bread Wheat (Triticum aestivum L.) at WolaitaSodo in Southern Ethiopia. International Journal of Research in Agriculture and Forestry, 5(10): 34-43.

[12] Bekele,H.,Verkuiji,H.,Mawangi,W.andTanner,D.G.,2000.Adaptation of improved wheat technologies in Addaba and Dodola Woredas of the Bale highlands of Ethiopia. CIMMYT/EARO, Addis Ababa, Ethiopia.: 55-83.

[13] Bhan, V.M. 1987. Weed Management in wheat in North plains of India.Advances in weeds science. Proceeding Weed Control Workshop, Islamabad, Pakistan, pp.163 - 171.

[14] Bibi,S.,Marwat, K.B., Hassan, G. and Khan,N.M.,2008.Effect of herbicides and wheat population on control of weeds in wheat. Pakistan. Journal of Weed Science Research, 14 (3-4):111-119.

[15] Birhanu, K., 1985. Progress of weed management in wheat production in Ethiopia.In: Regional Wheat Workshop for Eastern, Central and Southern Africa and Indian Ocean. Njoro, Kenya. Sept. 2-5,CIMMYT, Nairobi, Kenya :95-102.

[16] Chaudhary, S.U.,Hussain, M., Ali, M.A. and Iqbal, J.,2008.Effect of weed competition period on yield and yield components of wheat. Journal of Agriculture and Research, 46(1) :47-54.

[17] CSA.2018.Agricultural Sample Survey Series : Report on Area and Production for Major Crops(Private Holdings, Main Season).Statistical Bulletin No.586.Centeral Statistics Agency of Ethiopia, Addis Ababa, Ethiopia.:15-30.

[18] CSA.2018.Agricultural Sample Survey Series, 2017/18: Report on Area and Production for Major Crops(Private Holdings,Main Season).Statistical Bulletin No.586.Centeral Statistics Agency of Ethiopia,Addis Ababa, Ethiopia. pp.15-30.

[19] Dawit, D., Sharma, JJ., Tamado, T.,2014.Evaluation of Herbicides and Their Combinations for Weed Management in Bread Wheat (Triticum Aestivum L.) In Southern Ethiopia. International Journal of Novel Research in Life Sciences , 1: 31-47.

[20] Derksen, D.A., Anderson, R.L., Blackshaw, R.E. and Maxwell, B., 2002. Weed dynamics and management strategies for cropping systems in the northern Great Plains. Agronomy Journal, 94(2) :174-185.

[21] Gezu,G.andSoboka,H.,2001.Agronomic research recommendation and seed production maintenance techniques for major crops training manual for DA of highland Bale Sinan Ethiopia. pp.9-15.

[22] Haile, D. and Girma,F.,2010.Integrated Effect of Seeding Rate, Herbicide Dosage and Application Timing on Durum Wheat (Triticum Turgidum L. Var Durum) Yield, Yield Components and Wild Oat (Avena Fatua L.) Control in South Eastern Ethiopia. Ethiopian Journal of Science, 2:12-26.

[23] Malhi, S.S., Johnston, A.M., Loeppky, H., Vera, C.L., Beckie, H.J. and Bandara, P.M.S., 2007. Immediate effects of time and method of alfalfa termination on soil mineral nitrogen, 67 moisture, weed control, and seed yield, quality, and nitrogen uptake. Journal of Plant Weed Science, 39: 595-600

[24] Mathewos, A.,Tewodros,M. and Yasin,G.,2012. Participatory on-farm evaluation of improved bread wheat technologies in some districts of southern Ethiopia. Journal of Biology, Agriculture and Healthcare, 2(4): $85-91$.

[25] Mathewos, A.,Tewodros,M. and Yasin,G.,2012. Participatory on-farm evaluation of improved bread wheat technologies in some districts of southern Ethiopia. Journal of Biology, Agriculture and Healthcare, 2(4): pp.85-91.

[26] Megersa , K., Geleta, G., Tigist ,B., and Chemeda. B., 2017. Influence of post-emergence herbicides on major grass weeds and wheat (Triticum aestivum L.) at Gedo and Shambo, Western Oromia .Communications in Plant Sciences: 1-7

[27] Mennan, H. and Zandstra, B.H., 2005. Influence of wheat seeding rate and cultivars on competitive ability of Bifra (Bifora radians). Weed Technology, 19(1): 128-136.

[28] Munch, S., Lingner, U., Floss, D.S., Ludwig, N., Sauer, N. and Deising, H.B., 2008. The hemibiotrophic lifestyle of Colletotrichum species. Journal of plant physiology, 165(1) :41-51.

[29] Munsif,F., Ali,K.,Khan,I., Khan,H.U.and Anwar,M.,2009.Efficacy of various herbicides against weeds and their impact on yield of maize. Pakistan Journal of Weed Science Research, 15(2-3):191-198.

[30] Nadeem,M.A.,Ali,A. and Tanveer,A.S.I.F.,2006. Effect of different weed control practices and fertilizer levels on the weeds and grain yield of wheat. Pakistan Journal of Botany, 39(1):173.

[31] Nazir, M.A., Ahmad, M., Siddiq, M. and Ahmad, R., 1987. Wheat productivity as affected by seedling density and geometry of plantings. Sarhad Journal of Agriculture, 3(4): 409-415. 
[32] Oad, F.C., Siddiqui, M.H. and Buriro, U.A., 2007. Growth and yield losses in wheat due to different weed densities. Asian Journal of Plant Science, 6 :173-176.

[33] Radosevich,S.R.,Holt,J.S.and Ghersa,C.M.,2007.Ecology of weeds and invasive plants: relationship to agriculture and natural resource management. Pakistan Journal of Botany, 35(2) :142-155.

[34] Rao, A.N. and Nagamani, A., 2010. Integrated weed management in India-revisited. Indian Journal of Weed Science, 42(3\&4) :123-135.

[35] Rezene,F.,1985.Review of weed science research activities in wheat and barley. In:A Review of Crop Protection Research in Ethiopia. Tsedeke Abate (Ed.),IAR, Addis Ababa, Ethiopia. :121-148.

[36] Shah, S.A., Harrison, S.A., Boquet, D.J., Colyer, P.D. and Moore, S.H., 1994. Management effects on yield and yield components of late-planted wheat. Crop science, 34(5):1298-1303.

[37] Sharma, S .N and Singh, K.R, 2011. Seed rate and weed management on yield and nutrient uptake of wheat (Triticum aestivum). Indian Journal of Agricultural Sciences, 81 (12): 1174-1179,

[38] Shrestha,A.,Hanson,B.D.,Fidelibus,M.W.andAlcorta,M.,2010.Growth,phenology and intra specific competition between glyphosate-resistant and glyphosate-susceptible horse weeds (Conyza canadensis) in the San Joaquin valley of California.Weed Science, 58: 147-153.

[39] Tana,T.,Lemlem,M.and Dejene,M.,2018.Determination of Critical Period of Weed Competition in Bread Wheat Triticum aestivum L.at Haramaya,Eastern Ethiopia ,Doctoral dissertation,Haramaya University:1-92

[40] Tanner,D.G and Grief,S.,1991.Weed control research conducted on wheat in Ethiopia. pp. In:Wheat Research in Ethiopia: AHistorical Perispective.Hailu Gebre-Mariam, Tnner, D.G. and Mengistu, H. (Eds,). IAR/CIMMYT.Addis Ababa, Ethiopia : 235-276.

[41] Terefe, H., Denberu ,E. and Woldesenbet ,A., 2016.Effects of different weeding time of Ryegrass on growth and yield components of Wheat (Triticum spp.)in Jimma Area, Southwest Ethiopia. International Journal of Research Granthaalayah, 4(10) : 111-117.

[42] Thompson, K. and Grime, J.P., 1979. Seasonal variation in the seed banks of herbaceous species in ten contrasting habitats. The Journal of Ecology : 893-921.

[43] Tilman,D.,1980. Resources: Agraphical mechanistic approach to competition and predation. The American Naturalist, 116(3):362-393.

[44] USDA,2019.World Agricultural Production and Agricultural projections. Oxford University Press.pp.32

[45] USDA,2019.World Agricultural Production and Agricultural projections.Oxford University Press.pp.32

[46] Zahara ,M. and Shugute,A.,2017.Evaluation of Sequential Application of Herbicides for Broad and Grass Weed Management in Durum Wheat, Ethiopia. American Journal of Environmental and Resource Economics, 1:32-36.

[47] Zegeye, T., Taye,G., Tanner,D., Verkuiji, H., Agidie, A. and Mwangi,W.2001.Adoption of improved bread wheat varieties and inorganic fertilizer by small-scale farmers in Yelmana Densa and Farta districts of Northwestern Ethiopia.. In Proceedings of the First International Congress of Wheat EARO and CIMMYT. Mexico City,Mexico :315 - 566.

Citation: Bogale Ayana, " Wheat Production as Affected by Weed Diversity and Other Crop Management Practices in Ethiopia” International Journal of Research Studies in Agricultural Sciences (IJRSAS), 2020; 6(9), pp. 14-21, https://doi.org/10.20431/2454-6224.0609003

Copyright: (C) 2020 Authors. This is an open-access article distributed under the terms of the Creative Commons Attribution License, which permits unrestricted use, distribution, and reproduction in any medium, provided the original author and source are credited. 